\title{
On an Aitken-Steffensen-Newton type method
}

\author{
ION PĂVĂLOIU
}

\section{ABSTRACT.}

We consider an Aitken-Steffensen type method in which the nodes are controlled by Newton and two-step Newton iterations. We prove a local convergence result showing the $q$-convergence order 7 of the iterations. Under certain supplementary conditions, we obtain monotone convergence of the iterations, providing an alternative to the usual ball attraction theorems.

Numerical examples show that this method may, in some cases, have larger (possibly sided) convergence domains than other methods with similar convergence orders.

\section{REFERENCES}

[1] Amat, S. and Busquier, S., A two-step Steffensen's method under modified convergence conditions, J. Math. Anal. Appl., 324 (2006), 1084-1092

[2] Amat, S., Busquier, S. and Candela, V., A class of quasi-Newton generalized Steffensen methods on Banach space, J. Comput. Appl. Math., 149 (2002), 397-406

[3] Argyros, I. K. and Hilout, S., On the local convergence of fast two-step Newton-like methods for solving nonlinear equations J. Comput. Appl. Math., 245 (2013), 1-9

[4] Beltyukov, B. A., An analogue of the Aitken-Steffensen method with controlled step, URSS Comput. Math. Math. Phys., 27 (1987), No. 3, 103-112

[5] Cătinaş, E., On some Steffensen-type iterative methods for a class of nonlinear equations, Rev. Anal. Numér. Théor. Approx., 24 (1995), No. 1-2, 37-43

[6] Chun, C., Certain improvements of Chebyshev-Halley methods with accelerated fourth-order convergence, Appl. Math. Comput., 189 (2007), No. 1, 597-601

[7] Chun, C., A geometric construction of iterative formulas of order three, Appl. Math. Lett., 23 (2010), 512-516

[8] Cordero, A. and Torregrosa, R. J., A class of Steffensen type method with optimal order of convergence, Appl. Math. Comput., 217 (2011), 7653-7659

[9] Cordero, A., Torregrosa, J. R. and Vassileva, M. P., A family of modified Ostrowski's methods with optimal eighth order of convergence, Appl. Math. Lett., 24 (2011), No. 12, 2082-2086

[10] Hongmin, R., Qinghio, W. and Weihong, B., A class of two-step Steffensen type methods with fourth order convergence, Appl. Math. Comput., 209 (2009), No. 2, 206-210

[11] Jain, P., Steffensen type method for solving nonlinear equations, Appl. Math. Comput., 194 (2007), 527-533

[12] Kou, J. and Wang, X., Some improvements of Ostrowski's method, Appl. Math. Lett., 23 (2010), No. 1, 92-96

[13] Liu, L. and Wang, X., Eighth-order methods with high efficiency index for solving nonlinear equations, Appl. Math. Comput., 215 (2010), No. 9, 3449-3454

[14] Ortega, J. M. and Rheinboldt, W. C., Iterative Solution on Nonlinear Equations in Several Variables, Academic Press, New York, 1970

[15] Ostrowski, M. A., Solution of equations and systems of equations, Academic Press, New York, 1982

[16] Păvăloiu, I., and Cătinaş, E., On a robust Aitken-Newton method based on the Hermite polynomial, Appl. Math. Comput., 287-288 (2016), 224-231

[17] Păvăloiu, I., Approximation of the root of equations by Aitken-Steffensen-type monotonic sequences, Calcolo 32 (1995), No. 1-2, 69-82

[18] Păvăloiu, I., Bilateral approximations of solutions of equations by order three Steffensen-type methods, Studia. Univ. "Babeş-Bolyai", Mathematica (Cluj), LI (2006), No. 3, 87-94

Received: 22.09.2017; In revised form: 20.01.2018; Accepted: 27.01.2018

2010 Mathematics Subject Classification. 65H05.

Key words and phrases. nonlinear equations, Aitken-Steffensen method, Newton method, inverse interpolatory polynomial, monotone convergence. 
[19] Păvăloiu, I., and Cătinaş, E., On a Steffensen-Hermite method of order three, Appl. Math. Comput., 215 (2009), 2663-2672

[20] Păvăloiu, I. and Cătinaş, E., Bilateral approximations for some Aitken-Steffensen-Hermite type method of order three, Appl. Math. Comput., 217 (2011), 5838-5846

[21] Păvăloiu, I. and Cătinaş, E., On an Aitken-Newton-type method, Numer. Algor., 62 (2013), No. 2, 253-260

[22] Păvăloiu, I. and Cătinaş, E., On a Newton-Steffensen-type method, Appl. Math. Lett., 26 (2013), No. 6, 659-663

[23] Petković, M. S., On a general class of multipoint root-finding methods of high computational efficiency, SIAM J. Numer. Anal., 47 (2010), No. 6, 4402-4414

[24] Quan, Z., Peng, Z. and Wenchao, M., Variant of Steffensen secant method and applications, Appl. Math. Comput, 216 (2010), No. 12, 3486-3496

[25] Sharma, J. R., A composite third order Newton-Steffensen method for solving nonlinear equations, Appl. Math. Comput., 169 (2005), 342-346

[26] Zhanlav, T., Chuluunbaatar, O. and Ulziibayar, V., Two-sided approximation for some Newtons type methods, Appl. Math. Comp., 236 (2014), 239-246

TIBERIU POPOVICIU INSTITUTE OF NUMERICAL ANALYSIS

ROMANIAN ACADEMY

P.O. BOX 68-1, ROMANIA

E-mail address: pavaloiulictp.acad.ro 